thing new to say, something based upon experiences and observations. These are by no means all his own, for he has the ability to see with the eyes of other people, as well as with his own. He is thus able to bring into his pages a rich mass of new matter which gives them additional interest and value.

This new book consists of essays and papers, all of which have been presented elsewhere and are now brought together in accordance with the author's plan. Thus, while a collection of essays, it is not without unity. "In making these essays," the author says in his preface, "I have constantly had in mind their collection and publication, and have therefore endeavored to discuss the leading problems associated with the variation and evolution of cultivated plants, in order that the final collection should be somewhat consecutive."

The following sentences from the preface will give the reader a general idea of the author's position. "The underlying motive of the collection is the emphasis which is placed upon unlikenesses, and of their survival because they are unlike. The author also denies the common assumption that organic matter was originally endowed with the power of reproducing all its corporeal attributes, or that, in the constitution of things, like produces like. He conceives that heredity is an acquired force, and that, normally or originally, unlike produces unlike." The author's a priori reasons for belief in the hypothesis of evolution are "the two facts that there must be struggle for existence from the mere mathematics of propagation, and that there have been mighty changes in the physical character of the earth, which argue that organisms must either have changed or perished." On the other hand, "the chief demonstrative reason for belief in evolution is the fact that plants and animals can be and are modified profoundly by the care of man."

The body of the book is in three 'parts,' the first including essays touching the general fact and philosophy of evolution; second, those expounding the fact and causes of variation, and third, those tracing the evolution of particular types of plants. The first essay gives name to the book. In it the author discusses (1) the nature of the divergences of plants and animals, suggesting the Mycetozoa as the point of divergence; (2) the origin of differences, holding that all plants and animals came from one original life-plasma which had the power of perpetuating its physiological but not its structural identity; no two organisms ever being exactly alike, it follows that unlike produces unlike; (3) the survival of the unlike, this being an extension of our notion of the meaning of the phrase ' the survival of the fittest,' by showing that the fittest are the unlike.

The author gives us some interesting pages on the species dogma, in which he pointedly shows the inconsistency of those who demand experimental evidence of the evolution of a species, and yet reject 'horticultural species' because they have been produced under cultivation. Many examples are given of the origination of well-marked 'varieties,' which are more different from the species from which they sprung than are the recognized species from one another. Here Professor Bailey's experience as a horticulturist enables him to cite striking examples of what the candid reader must admit are good species evolved through man's selection. Thus we seem to have made species of of beans (Phaseolus), tomato (Lycopersicum), maize (Zea), soy-beans (Glycine), etc. The horticulturist who is familiar with the plasticity of plants, and who is accustomed to see new and persistent forms arise, cannot help being an evolutionist, nor can he help being impatient with the botanist who refuses to accept such forms as true varieties or species, as much entitled to recognition as those whose origin we do not happen to know.

Charles E. Bessey.

The University of Nebraska.

\section{A Popular Handbook of the Ornithology of Eastern}

North America. By Thomas Nuttall. 2d

Revised and Annotated Edition, by MoNtague Chamberlain. With additions and 110 illustrations in colors. Vol. I., The Land Birds. Vol. II., Game and Water Birds. Boston, Little, Brown \& Company. October, 1896.

For more than half a century students of North American ornithology have had three works which by common consent came to be 
regarded as classics. To lovers of birds the names of their authors, Audubon, Wilson and Nuttall, are as familiar as those of Milton, Dante and Shakespeare. Nuttall's book was the less pretentious of the three, having no colored plates and selling at a price which brought it within reach of a large constituency.

Nuttall was primarily a botanist, and not a few of his admirers who know him only from the excellence of his ornithological writings will be surprised to learn that for about ten years (1825-1834) he was Curator of the Botanic Garden and lecturer on natural history at Harvard, being Asa Gray's predecessor; and that the high character of his work placed hirn in the front rank of early American botanists.

In seeking new plants he made an expedition into Arkansas, and afterward, in company with Capt. Wyeth and J. K. Townsend, crossed the continent from Atlantic to Pacific, following the difficult overland route later known as 'The Oregon Trail.' His field work led him into all sorts of out-of-the-way places where he was constantly meeting strange and interesting birds. That he took an affectionate interest in their doings is shown by his biographies, which are original, faithful and entertaining and show an intimate personal familiarity with the species of which he wrote. Besides, they furnished what was then so much needed, a brief narrative of the life history, breeding habits and distribution of each as at that time known. In speaking of the book a modern writer has said: "Nuttall, like good wine, does not deteriorate with age." The original edition was long ago exhausted and for many years has commanded a relatively high price-the two volumes commonly selling for $\$ 25$, or even $\$ 30$.

In order to keep this execellent work within reach of the ever-increasing number of students and lovers of birds, Mr. Montague Chamberlain brought out, in 1891, a new and revised edition. The new edition differed from the original in several important respects: While the text and squence of the biographies were in the main unchanged, the birds were given their modern names, Western species were omitted, the descriptions of species were rewritten, a paragraph was added giving the geographic range as at present known, and additional species were in- cluded so as to embrace all the birds now known from the eastern United States and Canada. In all cases, the additional matter was printed in different type from the body of the work, so that Nuttall's original text was clearly set off from the matter contributed by the editor. The title page was misleading, as it failed to indicate the fact that the Western species had been left out, but in the new edition (1896) this is corrected, the new title page reading: 'A Popular Handbook of the Ornithology of Eastern North America.' The book is printed from the same plates as the previous edition, but corrections and additions have been made in the matter contributed by the editor. It is illustrated by text figures and colored plates. The latter might better have been omitted, although it is true that the majority of them may be recognized if looked at through a veil or smoked glass to deaden the unnaturally brilliant colors so characteristic of cheap chromolithographs. It is only fair to the author to state that he is in no way responsible for these plates; they were introduced by the publishers against his desire. The text figures are much better. They are of two kinds: (1) cuts borrowed from Baird, Brewer and Ridgway's History of North American Birds and mostly of high excellence; and (2) figures drawn for the book and mostly unsatisfactory. The latter have a coarse look and evidently were intended for greater reduction; they suffer by contrast with the more finished drawings among which they are scattered.

Mr. Chamberlain has done a public service in enabling the younger generation of bird students to add this classic to their libraries. This will be especially appreciated by those who care more for a bird in the bush than a bird in the hand-who love birds for what they are and what they do in life-for Nuttall's biographies possess a freshness and charm which time can never efface.

C. H. M.

The Cell. Outlines of General Anatomy and Physiology. By Dr. Oscar Hertwig. Translated by M. Campbell and edited by $\mathrm{H}$. J. Campbell, M. D. London, Swan, Sonnenschein \& Co.; New York, Macmillan \& Co. 1895. 8vo., cloth, 368 pp., 168 figs. $\$ 3.00$. 